\title{
Investigation of Cryptosporidium spp. in breeding nucleus of capuchin monkeys
}

\section{(Sapajus spp.)}

\author{
Investigação de Cryptosporidium spp. no núcleo reprodutivo de macacos-prego (Sapajus spp.) \\ La investigación de Cryptosporidium spp. en el núcleo reproductor de los monos capuchinos
}

(Sapajus spp.)

Thaís Weinstein Barbosa

ORCID: https://orcid.org/0000-0001-9167-1691

São Paulo State University, Brazil

E-mail: thais.weinstein@gmail.com

Sandra Valéria Inácio

ORCID: https://orcid.org/0000-0001-9436-3790

São Paulo State University, Brazil

E-mail: sandra_byol@yahoo.com.br

Gilberto Chiantinelli Ferreira

ORCID: https://orcid.org/0000-0002-4217-0249

São Paulo State University, Brazil

E-mail: gchiantelli@gmail.com

José Américo de Oliveira

ORCID: https://orcid.org/0000-0002-0158-7785

São Paulo State University, Brazil

E-mail: jose.americo-oliveira@unesp.br

Sérgio Diniz Garcia

ORCID: https://orcid.org/0000-0002-5848-0516

São Paulo State University, Brazil

E-mail: sergio@fmva.unesp.br

Débora Regina Romualdo da Silva

ORCID: https://orcid.org/0000-0001-6413-6861

São Paulo State University, Brazil

E-mail: deboraregina1996@outlook.com

Cláudia Misue Kanno

ORCID: https://orcid.org/0000-0001-8918-1079

São Paulo State University, Brazil

E-mail: claudia.kanno@unesp.br

Marcela Brode Goe

ORCID: https://orcid.org/0000-0002-5929-8396

São Paulo State University, Brazil

E-mail: marcela.goes@unesp.br

Lara Braidotti Gomes

ORCID: https://orcid.org/0000-0002-5247-7463

São Paulo State University, Brazil

E-mail: laradotti@hotmail.com

Jancarlo Ferreira Gomes

ORCID: https://orcid.org/0000-0002-2466-7315

University of Campinas, Brazil

E-mail: jgomes@ic.unicamp.br

Katia Denise Saraiva Bresciani

ORCID: https://orcid.org/0000-0002-8767-8855

São Paulo State University, Brazil

E-mail: katia.bresciani@unesp.br

\begin{abstract}
Animals of the primate order are highly susceptible to parasitic infections due to their social organization, often in groups and interaction between individuals, facilitating the transmission of pathogenic agents, and may be even more prevalent in areas modified by anthropic action. The occurrence of the protozoan Cryptosporidium spp. in wildlife animals in captivity or free-living it characterizes great importance of Public Health mainly for its zoonotic potential. This parasite has a cosmopolitan distribution, causes gastrointestinal infection, and its transmission occurs via the fecal-oral route, either through water or through contaminated food. Cryptosporidiosis affects mammals, birds, reptiles and fish, this significant zoonotic potential, in addition to being directly related to the living conditions of the host and the quality of the environment. We investigated the occurrence of Cryptosporidium spp. in primates located
\end{abstract}


at the Tufted Capuchin Monkey Procreation Center (School of Dentistry of Araçatuba - UNESP). Fecal samples from 49 asymptomatic primates of the species Sapajus spp. species were collected below their individual cages, the soil was lined with a plastic bag, thus hindering environmental contamination. The search for oocysts was carried out using the technique of Negative Malachite Green Staining, finding negativity in all samples examined, which suggests the absence of the protozoan Cryptosporidium spp. in primates studied in the breeding center of capuchin monkeys (Sapajus spp.), noting that they were asymptomatic.

Keywords: Coccidiosis; Primates; Zoonosis.

\section{Resumo}

Os animais da ordem primata são altamente susceptíveis a infecções parasitárias devido à sua organização social, frequentemente em grupos e interação entre indivíduos, facilitando a transmissão de agentes patogênicos, podendo ser ainda mais prevalentes em áreas modificadas por ação antrópica. A ocorrência do protozoário Cryptosporidium spp. em animais selvagens em cativeiro ou de vida livre caracteriza grande importância de Saúde Pública principalmente por seu potencial zoonótico. Este parasito apresenta distribuição cosmopolita, causa infecção gastrointestinal e sua transmissão ocorre pela via fecal-oral, seja por via hídrica ou por alimentos contaminados. A criptosporidiose afeta mamíferos, aves, répteis e peixes, apresentando significativo potencial zoonótico, além de estar diretamente relacionada às condições de vida do hospedeiro e à qualidade do meio ambiente. Nós investigamos a ocorrência de Cryptosporidium spp. em primatas localizados no Centro de Procriação do Macaco-prego (Faculdade de Odontologia de Araçatuba - UNESP). Amostras fecais de 49 primatas assintomáticos da espécie Sapajus spp. foram coletadas abaixo de suas gaiolas individuais, o solo foi forrado com saco plástico, dificultando assim a contaminação ambiental. A pesquisa de oocistos foi realizada pela técnica de Coloração Negativa de Verde Malaquita, encontrando-se negatividade em todas as amostras examinadas, o que sugere a ausência do protozoário Cryptosporidium spp. nos primatas estudados no núcleo de procriação de macacos-prego (Sapajus spp.), salientando que os mesmos eram assintomáticos.

Palavras-chave: Coccidiose; Primatas; Zoonose.

\section{Resumen}

Los animales del orden de los primates son altamente susceptibles a las infecciones parasitarias debido a su organización social, a menudo en grupos e interacción entre individuos, lo que facilita la transmisión de agentes patógenos, pudiendo ser incluso más prevalentes en áreas modificadas por la acción antrópica. Una ocorrência do protozoário Cryptosporidium spp. em animais selvagens em cativeiro ou de vida livre caracteriza grande importância de Saúde Public principalmente por seu potencial zoonótico. Este parasito apresenta distribuição cosmopolita, causa infecção gastrointestinal e sua transmissão ocorre pela via fecal-oral, seja por via hídrica ou por alimentos contaminados. La criptosporidiosis afecta a mamíferos, aves, reptiles y peces, con un importante potencial zoonótico, además de estar directamente relacionada con las condiciones de vida del huésped y la calidad del medio ambiente. Investigamos la aparición de Crytosporidium spp. en primates ubicados en el Centro de Cría de Monos Capuchinos (Facultad de Odontología de Araçatuba - UNESP). Muestras de heces de 49 primates asintomáticos de la especie Sapajus spp. debajo de sus jaulas individuales, el suelo se cubrió con una bolsa de plástico, lo que impidió la contaminación ambiental. La búsqueda de ooquistes se realizó mediante la Técnica de Tinción Negativa con Verde Malaquita, encontrándose negatividad en todas las muestras examinadas, lo que sugiere la ausencia del protozoario Cryptosporidium spp. en primates estudiados en el centro de cría de monos capuchinos (Sapajus spp.), observándose que eran asintomáticos.

Palabras clave: Coccidiosis; Primates; Zoonosis.

\section{Introduction}

Cryptosporidiosis, one of the main causes of diarrhea in vertebrate animals, disease caused by protozoa of the genus Cryptosporidium spp. (OIE, 2015; Madrid et al., 2015).

The most important species to public health are Cryptosporidium parvum and Cryptosporidium hominis due to their high zoonotic potential (Zahedi et al., 2016). However, 38 species of Cryptosporidium and more than 70 genotypes were identified by molecular techniques (Feng et al., 2018).

Some species are considered specific, such as Cryptosporidium ubiquitum in primates (Fayer et al., 2010), Cryptosporidium canis in dogs (Silva et al., 2016), Cryptosporidium meleagridis in birds (Laatamna et al., 2017), and Cryptosporidium parvum in ruminants (Holsback et al., 2018), being all zoonotic (Monis; Tompson, 2003; Araújo et al., 2007; Gai et al., 2008; Fayer et al., 2010; Mohammadian et al. 2019). 
The transmission of the protozoan occurs through the fecal-oral route or inhalation of the spores and there may be contamination of food, water and soil, with consequences in the sanitary, economic and social spheres (Stein et al., 2006; Chalmers et al., 2010; Johansen et al., 2014; OIE, 2015; Madrid et al., 2015). It is important to note that the Cryptosporidium oocyst is highly resistant in an aquatic environment, even after chlorine treatment processes (Hadi et al., 2016).

This parasite is related to cases of enterocolitis in primates (Levine, 1984). The most frequent symptoms of cryptosporidiosis are characterized by moderate to severe diarrhea with fever, vomiting and abdominal pain (Amaral et al., 2014; Kostopoulou et al., 2015).

Using Kinyoun's permanent staining technique, a 62.5\% prevalence of Cryptospuridium spp infection was found in primates (Vila Alvarez, 1994). On the other hand, few studies have been conducted to examine the ecology and epidemiology of this pathogen in places with a tropical climate, in which there is a great direct or indirect interaction between domestic, wild animals and man (Parsons et al., 2015).

Due to the high prevalence of the agent in primates (Vila Alvarez, 1994) and the growing identification of $C$. ubiquitum as an infectious parasite in humans ( $\mathrm{Li}$ et al., 2014), we investigated the occurrence of Cryptosporidium spp. in capuchin monkeys (Sapajus spp.) housed in a Breeding Nucleus.

\section{Methodology}

\subsection{Study location}

The experiment was carried out in Capuchin monkeys (Sapajus spp.), housed at the Tufted Capuchin Monkey Procreation Center (School of Dentistry of Araçatuba - UNESP) São Paulo, Brazil.

The monkeys were kept in individual stainless steel cages, with sides of perforated coin-type plate, separated by $8 \mathrm{~cm}$ and one and a half meters from the floor. The bottom of the cages consisted wire mesh and the other half a continuous stainless steel plate. The treated water supply for the animals were individualized, with a continuous flow, therefore the volume not consumed by the animals was discarded in a channel located on the floor of the room.

\section{Population}

A total of 49 asymptomatic monkeys (Sapajus spp.) were part of the study, 26 females and 23 males, among them, three were young, 30 adults and 16 elderly. All were bred in the facility.

\section{Ethics Committee}

This study was approved by the Ethics Committee on Animal Experimentation of the Faculty of Dentistry (FOA) of the São Paulo State University (UNESP) n ${ }^{\circ}$ 00589-2018 as well as by the Biodiversity Information and Authorization SystemSISBIO n ${ }^{\circ} 65508-1$.

\section{Sample collection and processing}

Fecal samples from 49 monkeys were collected below their individual cages (Figure 1), on the floor lined with a plastic bag (Figure 2). These fecal contents were packed in plastic flasks containing the animal's identification and stored under refrigeration until analysis. 
Research, Society and Development, v. 10, n. 11, e310101119459, 2021 (CC BY 4.0) | ISSN 2525-3409 | DOI: http://dx.doi.org/10.33448/rsd-v10i11.19459

Figure 1. Monkeys housed in individual stainless steel cages, with sides of perforated coin-type plate, separated by $5 \mathrm{~cm}$ to $8 \mathrm{~cm}$ and a meter and a half from the floor.

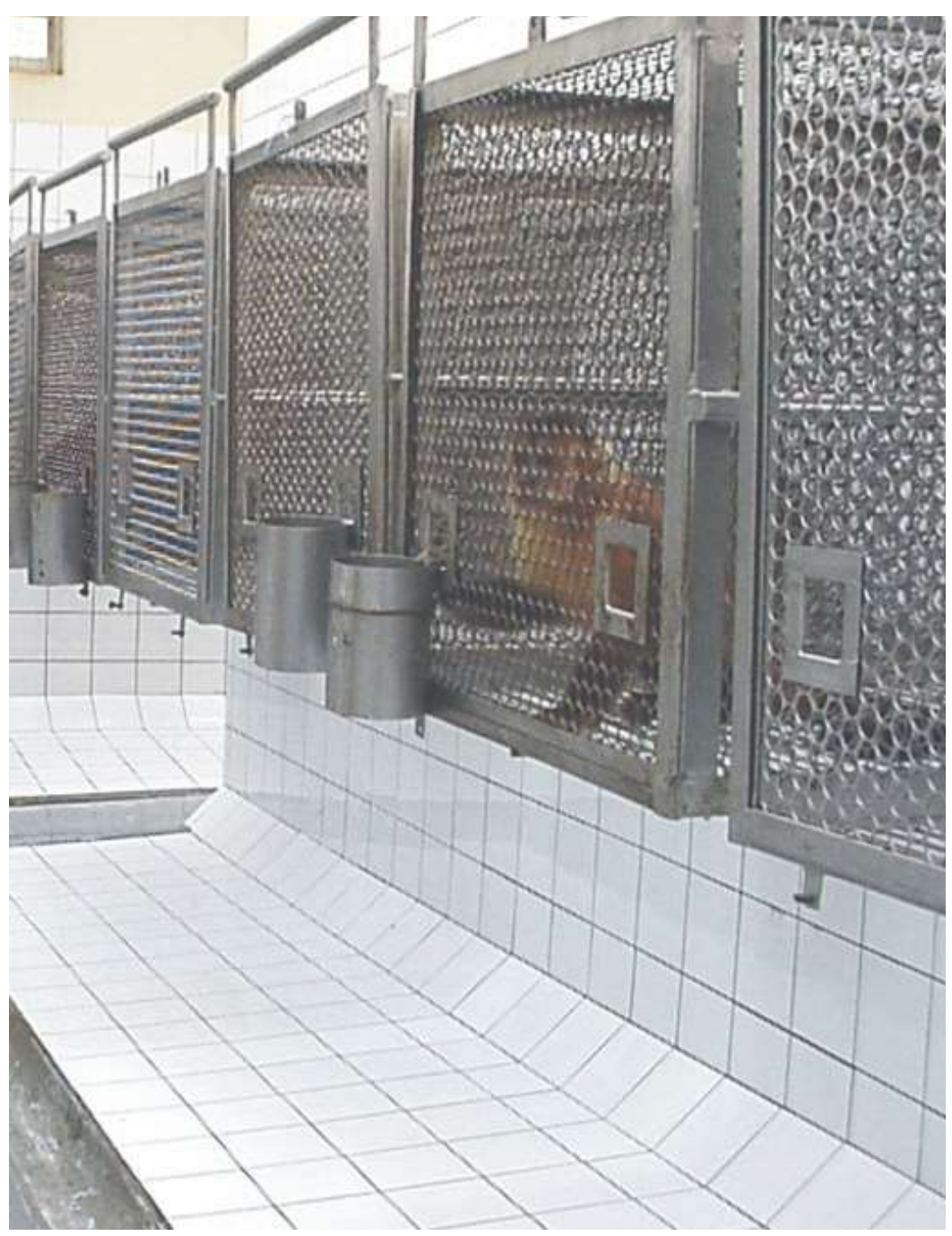

Source: Personal archive (2021). 
Research, Society and Development, v. 10, n. 11, e310101119459, 2021

(CC BY 4.0) | ISSN 2525-3409 | DOI: http://dx.doi.org/10.33448/rsd-v10i11.19459

Figure 2. The individual cages on the floor lined with a plastic bag half from the floor.

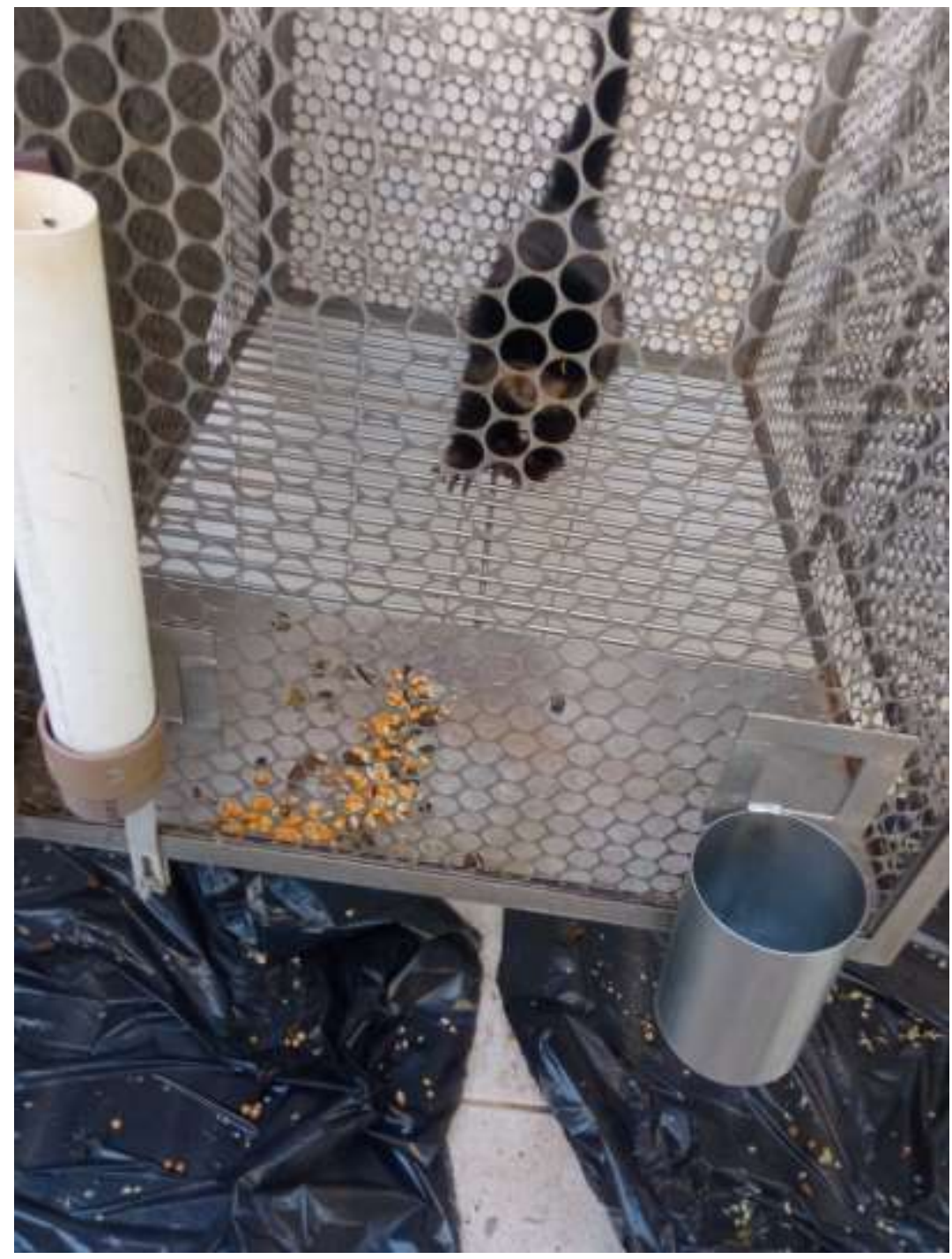

Source: Personal archive (2021).

The material was processed by modified centrifugal-sedimentation water/acetate (Meloni, Thompson, 1996) and observed using the Malachite Green Negative Staining Technique (Elliot et al., 1999) and Kinyoun (Lennette et al., 1985), in the optical microscopic at 40x magnification. 
Figure 3. Positive slide image for the protozoan Cryptosporidium spp. in bovine host according to the Malachite Green Negative Staining Technique.

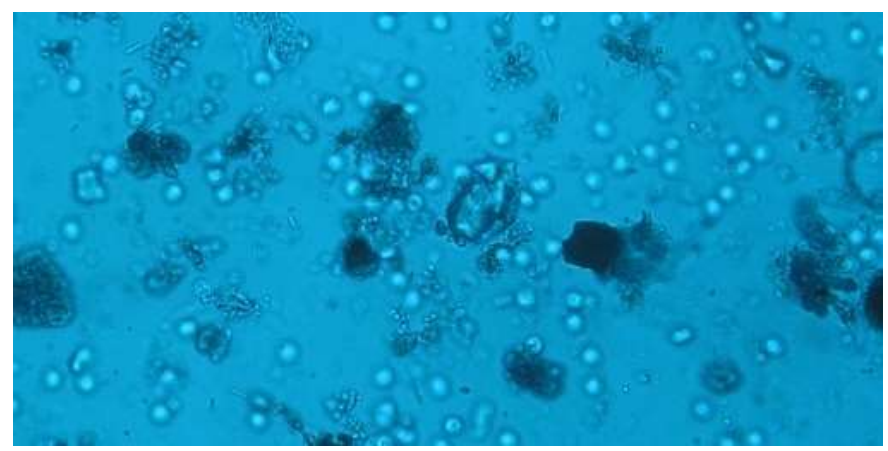

Source: Personal archive (2021).

Figure 4. Negative slide image for the protozoan Cryptosporidium spp. according to the Malachite Green Negative Staining Technique.

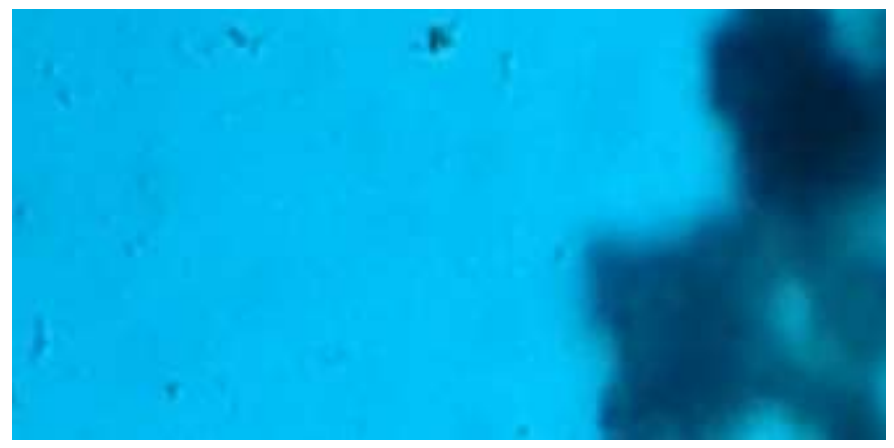

Source: Personal archive (2021).

The Figure 3 illustrates a positive slide for the endoparasite Crypstosporidium spp. and Figure 4 indicates a negative lamina for the same parasite. We note that the color of the bottom of the slide is green, while the parasite stands out without color.

\section{Results and Discussion}

In our study, through the parasitological analyzes Negative Staining of Malachite Green and Kinyoun, no Cryptosporidium spp. oocysts were observed in the population of capuchin monkeys of the species Sapajus spp..

The absence of oocysts in the feces of the population studied can be explained by the circumstances to which the animals were subjected, housed individually in cages, with space between them, individual water source and continuous flow, little or no contact with the animal's own feces or of other individuals, occurring minimal anthropic contact, only for nutritional management and maintenance. Such findings suggest that direct contact is an important condition for transmission to occur, as well as the quality of the water that animals have access to.

However, animals of the Primate Order are highly susceptible to parasitic infections, due to their social organization, in groups of intense interaction between individuals, facilitating the transmission of pathogens, which may be even more prevalent in areas modified by anthropic action (Trejó-Macias et al., 2007). 
There are limited studies that cross-examine the ecology and epidemiology direct or indirect contact between wild and domestic animals and humans (Parsons et al., 2015).

Nonetheless, in a study carried out using PCR (Polymerase Chain Reaction) as a diagnostic method, it was found that $4.30 \%$ of humans, $16.00 \%$ of primates and $9.60 \%$ of domestic animals were infected with Cryptosporidium. Although the condition of contact between primates and humans was varied, there was direct contact between animals (Parsons et al., 2005), showing the importance of interaction between individuals for the dissemination of the parasite.

It is important to note that the infectious evolutionary forms of Cryptosporidium spp. are highly resistant to environmental factors and can contaminate food, water and soil (Madrid et al., 2015). This fact was proven in a study in which 18 samples of four species of captive primates were analyzed by the centrifugal-flotation method with zinc sulfate. From the results obtained in this study, 10 of the animals were confirmed positive for the protozoan. The water consumed by them was also analyzed and a high number of oocysts was detected (Silva et al., 2008).

Also, in another study carried out in Paraná, there was a prevalence of $58.06 \%$ for this protozoan in the population of primates in question and, among all the pathogens researched using the modified Ziehl-Neelsen technique, Cryptosporidium presented a higher level of infection, with $49.15 \%$ of occurrence. According to the author, this result can be explained by the interaction of animals with keepers, veterinarians, park visitors and each other, in addition to the source of water and shared food (Snak et al., 2015), reinforcing its zoonotic potential as well as the environmental source of transmission and spread of this infection.

\section{Conclusion}

In our study, through the parasitological analysis of the Negative Malachite and Kinyoun Green Staining Technique, there was no positivity of Cryptosporidium spp. in the population of capuchin monkeys of the species Sapajus spp. housed in the breeding center of capuchin monkeys (Sapajus spp.). More research are encouraged, especially with wild animals in captivity or free-living to elucidate epidemiological points, transmission, zoonotic and pathogenic species causing damage to both primates and humans, since when they are in captivity the transmissibility among this public is longer range.

\section{References}

Amaral, A. S. Z., Aquino, M. C. C., Viol, MA et al (2014). Infecção por Cryptosporidium spp. em cordeiros e seu potencial zoonótico: revisão. Unimar Ciências, 23, 1-2.

Araújo, A. J. U. S., Gomes, A. H. S., Almeida, M. E., Kanamura, H. Y. (2007). Detecção de Cryptosporidium melagradis em amostras fecais em pacientes HIV positivos no Brasil. Revista Panamericana de Infectologia, 9, 2, 38-40.

Chalmers, R. M., Davies, A. P. (2010). Minireview: clinical cryptosporidiosis. Experimental Parasitology, 124, 138-46.

Silva, A. S., Coradini, G. P., Gressler, L. T. et al (2008). Ocorrência de protozoários gastrintestinais em primatas mantidos em cativeiro na região sul do Brasil. Ciência Rural, Santa Maria, 38, 2658-2661.

Elliot, A., Morgan, U., Thompson, R. C. (1999). Improved staining method for detecting Cryptosporidium oocysts in stools using malachite green. The Journal of General and Applied Microbiology, 45, 139-142.

Fayer, R., Santín, M., Macarisin, D. (2010). Cryptosporidium ubiquitum n. sp. in animals and humans. Veterinary Parasitology, 172 , $23-32$.

Feng, Y., Ryan, U. M., Xiao, L. (2018). Genetic diversity and population structure of Cryptosporidium. Trends Parasitology, 34, 997-1011.

Hadi, M. et al (2016). Contribution of environmental media to cryptosporidiosis and giardiasis prevalence in Tehran: a focus on surface waters. Environ Sci Pollut Res Int, 23, 19317-19329.

Holsback, L., Lima, H. E., Vidotto, O. et al (2018). Ocorrência de Cryptosporidium em ruminantes da mesorregião norte pioneiro do Estado do Paraná, Brasil. Brazilian Journal of Veterinary Parasitology, 27, 248-253.

Johansen, O. H, Hanevik, K., Thrana, F. et al (2014). Symptomatic and asymptomatic secondary transmission of Cryptosporidium parvum following two related outbreaks in schoolchildren. Epidemiology and Infection, 143, 1-8. 
Kostopoulou, D., Casaert, S., Tzanidakis, N. et al (2015). The occurrence and genetic characterization of Cryptosporidium and Giardia species in foals in Belgium, The Netherlands, Germany and Greece. Veterinary Parasitology, 211, 170-174.

Laatamna, A. E., Holubová, N., Sak, B. et al (2017). Cryptosporidium meleagridis and C. baileyi (Apicomplexa) in domestic and wild birds in Algeria. Folia Parasitologica, 64, 18.

Lennette, E. H., Balows, A., Hausler, J. W. J. et al (1985). Manual of clinical microbiology. Washington: American Society of Microbiology, 4 , 1149.

Levine, N. D. (1984). Taxonomy and review of the coccidian genus Cryptosporidium (Protozoa, Apicomplexa). Journal of Parasitology, 31, 94-98.

Madrid, D. M. C., Bastos, T. S. A., Jayme, VS (2015). Emergência da criptosporidose e impactos na saúde humana e animal. Enciclopédia Biosfera, 11, 1150.

Meloni, B. P., Thompson, R. C. A. (1996). Simplified methods for obtaining purified oocysts from mice and for growing Cryptosporidium parvum in vitro. Journal of Parasitology, 82, 757-762.

Mohammadian, H., Azizi, H., Dabirzadeh, M. (2019). Genetic Study of Cryptosporidium with SSU-rRNA in Children Younger Than Ten Referring to Hospitals of Zabol, Southeast of Iran, Shiraz E-Medical Journal, 20, 4.

Monis, P. T., Thompson, R. C. A. (2003). Cryptosporidium and Giardia- -zoonoses: fact or fiction? Infection, Genetics and Evolution, 3, 233-344.

OIE (2015). Emerging and re-emerging zoonoses. Editorials.

Parsons, M. B., Travis, D., Lonsdorf, E. V. et al (2015). Epidemiology and Molecular Characterization of Cryptosporidium spp. in Humans, Wild Primates, and Domesticated Animals in the Greater Gombe Ecosystem. PLOS Neglected Tropical Diseases, 9, 1-13.

Silva, G. R., Santana, I. M.; Ferreira, A. C. M. S. et al (2016). Avaliação de fatores epidemiológicos e sanitários associados à infecção por Cryptosporidium spp. em cães domiciliados. Ciência animal brasileira, 17, 435-441.

Snak, A, Garcia, FG, Delgado, LES et al (2015). Ocorrência de Cryptosporidium spp. em animais silvestres do Parque municipal de Cascavel, Paraná, Brasil. Semina: Ciências Agrárias, 36, 4323-4332.

Stein, B., Stover, L., Gillem, A. et al (2006). The effect of lectins on Cryptosporidium parvum oocyst in vitro attachment to host cells. Journal of Parasitology, 92, 1-9.

Trejó-Macias, G., Estrada, A., Cabrera, M. A. M. et al (2007). Survey of Helminth Parasites in Populations of Alouatta palliate mexicana and A. pigra in Continuos and in Fragmented Habitat in Southern Mexico. International Journal of Primatoogy, 28, 931-945.

Vila, A. T. (1994). Cryptosporidium sp. em mamíferos Del zoológico de Barcelona. Barcelona: Universitat de Barcelona, Facultat de Farmácia, 3-14.

Zahedi, A., Paparini, A., Jian, F. et al (2016). Public health significance of zoonotic Cryptosporidium species in wildlife: Critical insights into better drinking water management. International Journal for Parasitology: Parasites and Wildlife, 5, 88-109. 